\title{
Lead absorption and renal dysfunction in a South African battery factory
}

\begin{abstract}
Rodney Ehrlich, Thomas Robins, Esme' Jordaan, Shirley Miller, Simphiwe Mbuli, Paul Selby, Sinclair Wynchank, Anthony Cantrell, Marc De Broe, Patrick D'Haese, Andrew Todd, Philip Landrigan
\end{abstract}

Department of Community Health, University of Cape Town, South Africa R Ehrlich

Department of Environmental and Industrial Health, University of Michigan School of Public

Health, USA

T Robins

South African Medical Research Council, Cape Town, South Africa

E Jordaan

P Selby

S Wynchank

Chemical Workers' Industrial Union, Johannesburg, South

Africa

S Miller

Industrial Health Research Group, Cape Town, South Africa $S$ Mbuli

National Centre for Occupational Health, Johannesburg, South Africa

A Cantrell

Department of Nephrology-

Hypertension,

University of Antwerp, Belgium

M De Broe

P D'Haese

Department of Community Medicine, Mount Sinai School of Medicine, New York,

USA

A Todd

P Landrigan

Corresponding author: Dr RI Ehrlich, Department of Community Health, University of Cape Town Medical School, Observatory

7925, Cape Town, South Africa. Tel: 002721406 6435; fax: 0027214066163 ; email:

EHRLICH@ANAT.UCT. AC.ZA

Accepted 12 January 1998

\begin{abstract}
Objectives-To test the association between inorganic lead $(\mathrm{Pb})$ exposure, blood pressure, and renal function in South African battery factory workers, with both conventional and newer measures of renal function and integrity.

Methods-Renal function measures included serum creatinine, urea, and urate $(\mathbf{n}=382)$. Urinary markers $(\mathbf{n}=199)$ included urinary N-acetyl- $\beta$-Dglucosaminidase (NAG), retinol binding protein, intestinal alkaline phosphatase, tissue non-specific alkaline phosphatase, Tamm-Horsfall glycoprotein, epidermal growth factor, and microalbuminuria.

Results-Mean current blood $\mathrm{Pb}$ was $\mathbf{5 3 . 5}$ $\mu g / d l$ (range 23 to 110), median zinc protoporphyrin $10.9 \mu \mathrm{g} / \mathrm{g}$ haemoglobin (range 1.9 to 104), and mean exposure duration 11.6 years (range 0.5 to 44.5 ). Mean historical blood $\mathrm{Pb}$, available on 246 workers, was $57.3 \mu \mathrm{g} / \mathrm{dl}$ (range 14 to 96.3 ). After adjustment for age, weight and height, positive exposure response relations were found between current blood $\mathrm{Pb}$, historical blood $\mathrm{Pb}$, zinc protoporphyrin (ZPP), and serum creatinine and urate. Blood pressure was not associated with $\mathrm{Pb}$ exposure. Among the urinary markers, only NAG showed a positive association with current and historical blood Pb.

Conclusion-An exposure-response relation between $\mathrm{Pb}$ and renal dysfunction across the range from $<40$ to $>70 \mu \mathrm{g} / \mathrm{dl}$ blood $\mathrm{Pb}$ was found in this workforce, with conventional measures of short and long term $\mathrm{Pb}$ exposure and of renal function. This could not be explained by an effect on blood pressure, which was not associated with $\mathbf{P b}$ exposure. The findings probably reflect a higher cumulative renal burden of $\mathrm{Pb}$ absorption in this workforce in comparison with those in recent negative studies. The results also confirm the need for strategies to reduce $\mathrm{Pb}$ exposure among industrial workers in South Africa. (Occup Environ Med 1998;55:453-460)
\end{abstract}

Keywords: lead; occupation; kidney

With the control of acute inorganic lead $(\mathrm{Pb})$ toxicity in many workforces exposed to $\mathrm{Pb}$ over the past few decades, attention has shifted to chronic or subclinical disorders attributable to $\mathrm{Pb}$ exposure. ${ }^{12}$ Among these chronic effects, hypertension and renal dysfunction may be of particular concern in South African workers, because of the high prevalence of hypertension noted in some local population studies. ${ }^{3}$

Historically, chronic renal and hypertensive disease has been documented in people or populations with high $\mathrm{Pb}$ absorption. ${ }^{15}$ Epidemiological studies have mostly not found an adverse effect of $\mathrm{Pb}$ on the kidney in exposed workers with concentrations of blood $\mathrm{Pb}$ of the order of $<50-60 \mu \mathrm{g} / \mathrm{dl},{ }^{16-13}$ which is the range into which the medical standards of several developed countries fall. One difficulty in showing such renal effects may be the insensitivity of traditional clinical tests of renal function in the detection of early kidney injury or altered function. ${ }^{2}$ There has thus been considerable interest in potential laboratory biomarkers of early or site specific effects on the kidney of $\mathrm{Pb}$ absorption. ${ }^{14}{ }^{15}$

The association between $\mathrm{Pb}$ and blood pressure, with or without renal dysfunction, has in turn been the subject of inconclusive epidemiological investigations, particularly in occupationally exposed groups with moderate levels of absorption. ${ }^{11617}$

The objective of this study was to examine the association between (a) a variety of measures of $\mathrm{Pb}$ exposure or absorption and $(b)$ blood pressure and renal integrity and function, in a South African workforce with a wide range of $\mathrm{Pb}$ exposure. As well as performing conventional renal function tests, a variety of urinary biomarkers of known or theoretical value in the measurement of early renal dysfunction or nephrotoxicity were measured.

\section{Methods}

A cross sectional study was conducted of 382 production employees of $\mathrm{a} \mathrm{Pb}$ acid battery plant in the city of East London on the east coast of South Africa. The workforce was predominantly black, ${ }^{\star}$ most employees had grown up in rural districts of the Eastern Cape Province, and all were men. All permanent production workers were invited to participate, as well as temporary workers (mainly on short contracts) over 37 years of age. The age restriction was applied for statistical efficiency, by adding a group of older short service workers to the study group so as to reduce confounding by age. Although all of the subjects had some exposure to $\mathrm{Pb}$, the wide range of exposure was

*Under apartheid, South Africans were divided into one of four racial groups; asian, black, coloured, and white. These catagories denote, to a varying extent, differences in socioeconomic status, diet, urbanisation. and experience of racial discrimination. 
such as to permit examination of exposureresponse associations.

The batteries are assembled by a conventional process. Exposures include inorganic $\mathrm{Pb}$ fume and $\mathrm{Pb}$ oxide, and $25 \%-35 \%$ sulphuric acid by weight in water. Measurements of $\mathrm{Pb}$ in air had been carried out in this plant only in recent years. A hygiene survey carried out six months before the study found measurements of $\mathrm{Pb}$ in air exceeding the South African occupational exposure limit of $0.15 \mathrm{mg} / \mathrm{m}^{3}$ in 14 out of 30 samples. The median $\mathrm{Pb}$ in air concentration was $0.145 \mathrm{mg} / \mathrm{m}^{3}$ and the range 0.01 to $5.48 \mathrm{mg} / \mathrm{m}^{3}$.

QUESTIONNAIRE

A questionnaire was administered by a single trained interviewer in the language of the subject (Xhosa, English, or Afrikaans). Questions covered demographic details, including periods lived in rural and urban areas; past medical illness including hypertension, diabetes mellitus, and kidney disease; analgesic use; smoking; alcohol use; physical activity; and dietary salt preference.

MEASUREMENT OF EXPOSURE AND ABSORPTION Lead absorption measures included current blood $\mathrm{Pb}$ and zinc protoporphyrin (ZPP) concentrations, which can be regarded as reflecting a balance between recent and cumulative $\mathrm{Pb}$ absorption. Long term measures of exposure and absorption were based on the duration of work with $\mathrm{Pb}$ and the average of all past and current blood $\mathrm{Pb}$ results.

A detailed occupational history was taken of jobs in this plant and elsewhere, including questions about exposure to heavy metals both at and outside of work. Service periods were checked against company records, and discrepancies were remedied by recontacting the company and employee if necessary.

In the current study, heparinised whole blood was collected in $\mathrm{Pb}$ free Vacutainer tubes. Blood $\mathrm{Pb}$ was measured by graphite furnace atomic absorption spectrophotometry (Perkin-Elmer 5000) in the national quality control scheme reference laboratory, which in turn participates in the United Kingdom national external quality assessment scheme for $\mathrm{Pb}$ and cadmium (Cd). Zinc protoporphyrin was measured in the same specimen on a haematofluorometer (Aviv) and expressed in $\mu \mathrm{g} / \mathrm{g}$ haemoglobin. Historical blood $\mathrm{Pb}$ measurements were available from 1974 to 1980 on fewer than five workers annually. Only from 1981 did the number of available blood results for any given year rise steadily, from 15 in 1981 to 377 in 1993. The median number of measurements per worker per year also rose from one to three. Most of these historical blood measurements had been done in one private laboratory with graphite furnace atomic absorption spectrophotometry. This laboratory participated in a national quality control scheme from 1979 onwards. Figure 1 shows the median blood $\mathrm{Pb}$ concentrations, with interquartile ranges. Although based on small numbers of specimens in the early years, the medians show a stable decline from the range

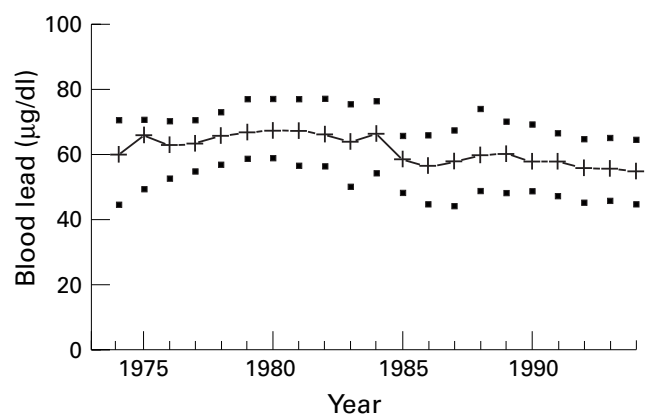

Median blood $\mathrm{Pb}$ concentrations, with interquartile ranges, 1974-94.

60 to $65 \mu \mathrm{g} / \mathrm{dl}$ between 1974 and 1984 to the range 55 to $59 \mu \mathrm{g} / \mathrm{dl}$ between 1985 and 1994 .

Reasonably complete historical blood $\mathrm{Pb}$ information - that is, from the first year of employment, was available on a subset of subjects only $(n=246)$. To avoid extrapolation to earlier periods, only this group was used to construct the historical blood $\mathrm{Pb}$ variables. These variables were $(a)$ cumulative blood $\mathrm{Pb}$ ( $\mu \mathrm{g} . \mathrm{y} / \mathrm{dl}$ ), the sum of average blood $\mathrm{Pb}$ in each year over all such years of employment, and (b) historical blood $\mathrm{Pb}$, calculated by dividing the cumulative blood $\mathrm{Pb}$ by duration of exposure.

BIOCHEMICAL AND HAEMATOLOGICAL TESTS Serum urea, creatinine, uric acid, haemoglobin, and packed cell volume were measured by routine automated methods (appendix 1). Urine was screened qualitatively for protein, blood, and glucose with a test strip (Combur 10 test).

Urine was collected from a stratified random sample of 199 members of the study group. Stratification was by tertile of current blood $\mathrm{Pb}$, so as to obtain a balanced distribution across the whole range of blood $\mathrm{Pb}$. Urine was collected in plastic containers, buffered, and stored at $4^{\circ} \mathrm{C}$ for transport to the laboratory. Seven urinary biomarkers were measured quantitatively (appendix 1). Six of these are regarded as markers of tubular injury or dysfunction: $\quad \mathrm{N}$-acetyl- $\beta$-D-glucosaminidase (NAG), retinol binding protein, tissue nonspecific alkaline phosphatase, intestinal alkaline phosphatase, Tamm-Horsfall glycoprotein, and epidermal growth factor. Microalbuminuria, a measure of glomerular dysfunction, was also measured. To standardise for varying diuresis, these biomarkers were all expressed /g urinary creatinine.

BLOOD PRESSURE, WEIGHT, AND HEIGHT A calibrated mercury sphygmomanometer was used to measure blood pressure. A registered nurse was trained by one of the researchers, with the aid of a double headed stethoscope, to record systolic pressure at the beginning of the consecutive run of Korotkow sounds (phase I) and diastolic pressure as the disappearance of the sounds (phase V). Three recordings were made, the subject resting for five minutes before the first recording, and one minute between each. The average of the three readings was used for systolic and diastolic 
Table 1 Exposure and lifestyle variables in a South African battery making workforce $(n=382)$

\begin{tabular}{|c|c|c|c|}
\hline & Mean (SD) & Median & Range \\
\hline Age $(y)$ & $41.2(8.3)$ & 41.0 & $21-71$ \\
\hline Weight $(\mathrm{kg})$ & $75.5(14)$ & 73.2 & $47-148$ \\
\hline Height $(\mathrm{cm})$ & $168.9(6.3)$ & 169.0 & 154-193 \\
\hline \multicolumn{4}{|l|}{ Lead exposure: } \\
\hline Blood lead $(\mu \mathrm{g} / \mathrm{dl})$ & $53.5(12.7)$ & 53.0 & $23-110$ \\
\hline $\mathrm{ZPP}(\mu \mathrm{g} / \mathrm{g} \mathrm{Hb})$ & $12.6(9.3)$ & 10.9 & $1.9-104$ \\
\hline Duration of exposure (y) & $11.6(6.8)$ & 10.5 & $0.5-44.5$ \\
\hline Historical blood lead $(\mu \mathrm{g} / \mathrm{dl})^{\star}$ & $57.3(15)$ & 58.7 & $14-96.3$ \\
\hline Cumulative blood lead $(\mu \mathrm{g} . \mathrm{y} / \mathrm{dl})^{\star}$ & $579.0(423)$ & 518 & $7-2681$ \\
\hline \multicolumn{4}{|l|}{ Smoking: } \\
\hline Ever smoked (\%) & 57.6 & - & - \\
\hline Current $(\%)$ & 52.4 & - & - \\
\hline Duration (y) & $20.4(8.7)$ & 20 & $3-49$ \\
\hline Pack-y & $10.5(7.5)$ & 9 & $0.6-58$ \\
\hline \multicolumn{4}{|l|}{ Alcohol: } \\
\hline Ever alcohol (\%) & 70.4 & - & - \\
\hline Current $(\%)$ & 67.0 & - & - \\
\hline Duration (y) & $11.8(11.0)$ & 11.0 & $0-47$ \\
\hline Weekly (g) & 218 & 159.0 & $0-1566$ \\
\hline
\end{tabular}

$\star_{n}=246$. Hb=Haemoglobin. as a categorical variable, as well as for the proportion of selected renal markers falling above upper reference levels. Age, height, and weight were entered into all of the models. Candidate covariates for the blood pressure regression included the alcohol and smoking measures, haemoglobin, physical exercise, dietary salt preference, years spent in an urban area, creatinine, urea, and uric acid. Candidate covariates entered into the renal outcome models included alcohol and smoking variables and diabetes.

Based on initial hypotheses, first order interactions between each of the $\mathrm{Pb}$ exposure variables and alcohol, smoking, and racial group were considered as candidate variables for entry into the relevant linear regression model.

ETHICS

The study was approved by the Ethics and Research Committee of the University of Cape Town. Signed informed consent was obtained from each participant. Subjects were individually informed of their results, and those with findings requiring action were counselled or referred to a medical practitioner.

About two years after the main study, a random sample of 40 workers from the original study group had bone $\mathrm{Pb}$ concentration measured in the left tibial midshaft with the technique of $\mathrm{K}$ $x$ ray fluorescence $(\mathrm{K}-\mathrm{XRF}) .^{18}$

As a result of recent contention over the contribution of $\mathrm{Cd}$ to increased NAG activity in workers exposed to $\mathrm{Pb},{ }^{19-21}$ a sample of 56 workers from the original study group had their blood $\mathrm{Cd}$ concentrations measured at two years. These 56 workers included 36 of the 40 subjects chosen for bone $\mathrm{Pb}$ testing, six others were followed up for persistent renal dysfunction, and 14 workers underwent annual medical surveillance. Cadmium was measured with graphite furnace atomic absorption spectrophotometry (Varian SpectrAA.30) in the same laboratory as was blood $\mathrm{Pb}$ in the main study.

\section{STATISTICAL ANALYSIS}

Spearman rank correlation coefficients $(r)$ were used to examine correlation between exposure measures. Blood pressure was analysed in two ways. With blood pressure as a continuous variable, the analysis was conducted both with and without subjects on reported antihypertensive treatment. For use as a categorical variable and to ensure enough numbers for analysis, a liberal definition of hypertension was used-that is, subjects on reported antihypertensive treatment, or who had both a systolic pressure $>140$ $\mathrm{mm} \mathrm{Hg}$ and a diastolic pressure $>90 \mathrm{~mm} \mathrm{Hg}$.

Separate regression analyses were conducted for the association between systolic blood pressure, diastolic blood pressure, creatinine, urea, uric acid, the urinary biomarkers, haemoglobin, and packed cell volume, and each of the $\mathrm{Pb}$ exposure variables, controlling for potential confounders. The associations of continuous outcomes with exposure variables and covariates of interest were tested in multiple linear regression, with the maximum $\mathrm{R}^{2}$ improvement technique to find the best subset of predictors. Logistic regression was used for hypertension

\section{Results}

A total of 382 workers participated, of whom 359 were permanent and 23 temporary employees. Of the original invited group of 368 weekly paid (unionised) employees, six did not participate. Participation of monthly paid (supervisory) staff was not solicited; however, 20 out of 82 requested to take part. Of the subjects studied, 341 were black, the remainder results from the first year of employment were available on 246 subjects.

Table 1 presents the age and $\mathrm{Pb}$ exposure status of the participants. The mean duration of service was 11.6 years, with $65 \%$ of the workforce having had between five and 15 years of exposure, and $12 \%$ fewer than five years of exposure. Exposure to $\mathrm{Pb}$ in jobs or activities outside of this company was uncommon.

Table 1 includes smoking and alcohol information. About half the workforce currently smoked, with a mean smoking history of 10.5 pack-years among smokers. A total of $67 \%$ of the workforce currently used alcohol, having an estimated mean weekly intake of $218 \mathrm{~g}$ alcohol among current users. (rough equivalents: 340 $\mathrm{ml}$ can of beer $=13 \mathrm{~g}$ alcohol; $175 \mathrm{ml}$ glass of wine $=15 \mathrm{~g} ; 50 \mathrm{ml}$ glass of spirits $=17 \mathrm{~g}$ ).

Table 2 presents renal function, haematological findings, and blood pressure. No reference range is provided for creatinine, as the upper limit of reference ranges for creatinine varies (somewhat arbitrarily) between 106 and $130 \mu \mathrm{mol} / 1$ in South African laboratories. The median serum creatinine in this group was $97 \mu \mathrm{mol} / 1$, with $6.5 \%$ of results falling between 120 and $129 \mu \mathrm{mol} / 1$ and a further $3.7 \%$ were $\geqslant 130 \mu \mathrm{mol} / 1$. The proportion of subjects classified as hypertensive (blood pressure $>140 / 90 \mathrm{~mm} \mathrm{Hg}$ or on antihypertensive treatment) was $7.9 \%$. Diabetes (defined as reporting diabetes or testing at least $1+$ positive being coloured or white. Historical blood $\mathrm{Pb}$ 
Table 2 Laboratory and clinical variables in a South African battery making workforce $(n=382)^{\star}$

\begin{tabular}{lcrll}
\hline & Mean $(\mathrm{SD})$ & Median & Range & $\begin{array}{l}\text { Laboratory } \\
\text { range }\end{array}$ \\
\hline Serum creatinine $(\mu \mathrm{mol} / \mathrm{l})$ & $99.6(16.2)$ & 97.0 & $59-184$ & $\dagger$ \\
Serum urea $(\mathrm{mmol} / \mathrm{l})$ & $5.6(1.5)$ & 5.5 & $2.4-17$ & $2.5-6.7$ \\
Serum urate $(\mu \mathrm{mol} / \mathrm{l})$ & $343.0(329.0)$ & 329.0 & $174-812$ & $210-430$ \\
Haemoglobin $(\mathrm{g} / \mathrm{dl})$ & $14.5(1.2)$ & 14.5 & $10.5-21.8$ & $13.0-18.0$ \\
Packed cell volume $(\%)$ & $42.7(3.5)$ & 42.6 & $31.6-62.9$ & $40.0-54.0$ \\
Systolic blood pressure $(\mathrm{mm} \mathrm{Hg})$ & $121.3(13.6)$ & 120.0 & $90-167$ & - \\
Diastolic blood pressure $(\mathrm{mm} \mathrm{Hg})$ & $75.7(10.0)$ & 75.3 & $33-104$ & - \\
\hline
\end{tabular}

^See appendix 2 for conversion factors.

†See text.

Table 3 Urinary biomakers in a South African battery making workforce $(n=199)$ *

\begin{tabular}{lccllll}
\hline & Mean $(S D)$ & Median & Range & $\begin{array}{l}\text { Normal } \\
\text { range }\end{array}$ & $\begin{array}{l}\text { \% Outside } \\
\text { normal range }\end{array}$ \\
\hline NAG (U/g creatinine) & $4.0(5.1)$ & 2.9 & $0.7-62.9$ & $<5.0$ & 23.0 \\
RBP $(\mu \mathrm{g} / \mathrm{g}$ creatinine) & 84.4 & $(122.9)$ & 58.1 & $9.9-1291.5$ & $<300$ & 3.5 \\
EGF $\mu$ g/g creatinine) & $20.3(11.1)$ & 17.5 & $3.7-67.2$ & $>10$ & 11.0 \\
THF (mg/g creatinine) & $30.2(25.4)$ & 27 & $1.8-219.6$ & $>10$ & 14.0 \\
IAP (U/g creatinine) & $0.32(0.48)$ & 0.16 & $0-3.6$ & $<2.0$ & 2.0 \\
TNAP (U/g creatinine) & $0.1(0.15)$ & 0.07 & $0-1.6$ & $<2.5$ & 0 \\
m-Alb (mg/g creatinine) & $9.3(19.3)$ & 3.1 & $0.32-520.4$ & $<25$ & 5.0
\end{tabular}

*See text and appendix 1 for description. NAG=Nacetyl- $\beta$-D-glucosaminidase; RBP=retinol binding protein; EGF=epidermal growth factor; THF=Tamm-Horsfall glycoprotein; $\mathrm{IAP}=$ intestinal alkaline phosphatase; TNAP=tissue non-specific alkaline phosphatase; $\mathrm{m}-\mathrm{Alb}=$ microalbuminuria.

for glycosuria with the dipstix method) was found in $2.9 \%$ of the group.

Table 3 presents the urinary markers, with the normal reference concentrations supplied by the laboratory. Of note is that $23 \%$ of the NAG test results fell above the normal range.

The different dimensions of $\mathrm{Pb}$ exposure represented by the $\mathrm{Pb}$ variables are reflected in their intercorrelations. Current blood $\mathrm{Pb}$ was moderately strongly correlated with ZPP

Table 4 Renal markers and lead exposure in a South African battery making workforce *

\begin{tabular}{|c|c|c|c|c|c|}
\hline & $n$ & $\begin{array}{l}\text { Serum creatinine } \\
(\mu \mathrm{mol} / \mathrm{l}) \\
\text { Mean }(S E)\end{array}$ & $\begin{array}{l}\text { Serum uric acid } \\
(\mu \mathrm{mol} / \mathrm{l}) \\
\text { Mean (SE) }\end{array}$ & $n$ & $\begin{array}{l}\text { Urinary NAG } \\
\text { (U/g creatinine) } \\
\text { Mean }(S E)\end{array}$ \\
\hline \multicolumn{6}{|c|}{ Current blood lead $(\mu \mathrm{g} / \mathrm{dl})$ : } \\
\hline $23-40$ & 48 & $95.4(2.2)$ & $313.6(12.1)$ & 27 & $(0.5)$ \\
\hline $41-50$ & 112 & $97.8(1.5)$ & $334.9(7.9)$ & 61 & $(0.3)$ \\
\hline $51-60$ & 115 & $100.2(1.4)$ & $339.2(7.8)$ & 59 & $3.9 \quad(0.3)$ \\
\hline $61-70$ & 73 & $101.4(1.8)$ & $370.9(9.8)$ & 37 & $(0.5)$ \\
\hline $71-110$ & 28 & $108.3(3.0)$ & $378.4(15.7)$ & 11 & $5.8(0.9)$ \\
\hline $\mathrm{p}$ For trend & & 0.008 & 0.0006 & & 0.09 \\
\hline \multicolumn{6}{|l|}{$\mathrm{ZPP}(\mu \mathrm{g} / \mathrm{g} \mathrm{Hb}):$} \\
\hline $1.9-4.9$ & 54 & $95.1(2.0)$ & $329.1(11.4)$ & 30 & $3.3(0.5)$ \\
\hline $5-9.9$ & 110 & $96.7(1.4)$ & $338.8(8.0)$ & 51 & $(0.4)$ \\
\hline $10-14.9$ & 90 & $98.7(1.5)$ & $338.9(8.8)$ & 49 & $(0.4)$ \\
\hline $15-19.9$ & 47 & $100.3(2.1)$ & $343.2(12.2)$ & 26 & $4.4(0.6)$ \\
\hline $20-24.9$ & 33 & $104.2(2.6)$ & $343.6(14.6)$ & 16 & $3.5(0.7)$ \\
\hline $25-104$ & 30 & $115.3(2.7)$ & $396.3(15.3)$ & 17 & $4.8 \quad(0.7)$ \\
\hline p For trend & & 0.02 & 0.006 & & 0.4 \\
\hline \multicolumn{6}{|l|}{ Duration (y): } \\
\hline $0.5-1.9$ & 26 & $96.3(3.2)$ & $327.9(17.0)$ & 19 & $(0.7)$ \\
\hline $2-4.9$ & 20 & $98.5(3.7)$ & $358.2(19.8)$ & 10 & $2.2 \quad(0.9)$ \\
\hline $5-9.9$ & 131 & $99.2(1.4)$ & $340.2(7.8)$ & 62 & $4.0 \quad(0.4)$ \\
\hline $10-14.9$ & 116 & $99.8(1.5)$ & $344.5(7.9)$ & 62 & $(0.3)$ \\
\hline $15-44.5$ & 89 & $101.2(1.8)$ & $348.1(9.7)$ & 45 & $(0.4)$ \\
\hline p For trend & & 0.7 & 0.7 & & 0.3 \\
\hline \multicolumn{6}{|c|}{ Cumulative blood lead ( $\mu$ g.y/dl): } \\
\hline $7-352.3$ & 64 & $97.6(2.0)$ & $332.1(11.1)$ & 32 & $(0.4)$ \\
\hline $352.4-533.3$ & 65 & $97.5(2.0)$ & $329.0(11.0)$ & 33 & $(0.4)$ \\
\hline $533.4-729.8$ & 62 & $101.9(2.0)$ & $342.3(11.2)$ & 36 & $(0.4)$ \\
\hline $729.9-2681$ & 55 & $101.3(2.3)$ & $359.5(12.7)$ & 24 & $(0.5)$ \\
\hline $\mathrm{p}$ For trend & & 0.3 & 0.3 & & 0.4 \\
\hline \multicolumn{6}{|c|}{ Historical blood lead $(\mu \mathrm{g} / \mathrm{dl})$ : } \\
\hline $14-40$ & 32 & $94.6(2.8)$ & $309.1(15.4)$ & 19 & $(0.5)$ \\
\hline $41-50$ & 35 & $98.3(2.7)$ & $361.9(14.9)$ & 18 & $(0.6)$ \\
\hline $51-60$ & 67 & $96.4(1.9)$ & $324.5(10.6)$ & 33 & $(0.4)$ \\
\hline $61-70$ & 57 & $101.4(2.1)$ & $338.8(11.5)$ & 33 & $(0.4)$ \\
\hline $71-96.3$ & 55 & $105.0(2.1)$ & $364.0(11.8)$ & 22 & $(0.5)$ \\
\hline $\mathrm{p}$ For trend & & 0.01 & 0.01 & & 0.1 \\
\hline
\end{tabular}

${ }^{\star}$ Adjusted in linear regression for age, height, and weight.

$\mathrm{NAG}=\mathrm{N}$-acetyl- $\beta$-D-glucosaminidase; $\mathrm{ZPP}=$ zinc protoporphyrin; $\mathrm{Hb}=$ haemoglobin . $(r=0.67)$ and historical blood $\mathrm{Pb}(r=0.66)$, less strongly with cumulative blood $\mathrm{Pb}(r=0.43)$, and weakly with duration $(r=0.18)$. Cumulative blood $\mathrm{Pb}$ was highly correlated with duration $(r=0.94)$, moderately strongly with historical blood $\mathrm{Pb}(r=0.58)$, and less strongly with ZPP $(r=0.32)$. All correlations were significant $(\mathrm{p}<0.05)$.

There was no significant association between any of the $\mathrm{Pb}$ exposure measures and either systolic or diastolic blood pressure, or hypertension defined categorically. After modelling, both systolic and diastolic blood pressure were positively associated in a multivariable regression model with age, weight, and weekly alcohol intake. Also, systolic blood pressure was positively associated with serum uric acid. There was no association between blood pressure and haemoglobin, smoking, physical activity, dietary salt preference, or years spent in an urban area.

Table 4 shows the associations between the $\mathrm{Pb}$ exposure variables and renal outcome variables from multiple linear regression analysis. For clearer exposition of exposure-response relations, the $\mathrm{Pb}$ exposure variables are categorised, and the renal outcomes adjusted for age, height, and weight.

Current blood $\mathrm{Pb}, \mathrm{ZPP}$, and historical blood $\mathrm{Pb}$ were all positively associated with both serum creatinine and uric acid. In the case of current and historical blood $\mathrm{Pb}$, the exposure response association is apparent across the whole range from $<40 \mu \mathrm{g} / \mathrm{dl}$ to $>70 \mu \mathrm{g} / \mathrm{dl}$. In the case of ZPP the range extends from $<5 \mu \mathrm{g} / \mathrm{g} \mathrm{Hb}$ to $>25 \mu \mathrm{g} / \mathrm{g} \mathrm{Hb}$. Entering weekly alcohol intake into the regression models for uric acid reduced the coefficient for current blood $\mathrm{Pb}$ slightly (from 1.55 to 1.36 ) but had otherwise no confounding effect.

The only significant association between urea and any of the $\mathrm{Pb}$ exposure variables was with ZPP (partial $r=0.2, p=0.0001$ ). Neither cumulative blood $\mathrm{Pb}$ nor duration of exposure was associated with creatinine, urea, or uric acid.

Urinary markers were tested in 199 subjects. There was no significant difference between those tested and the rest of the workforce $(\mathrm{n}=183)$ for mean current blood $\mathrm{Pb}(53.1 \mu \mathrm{g} / \mathrm{dl}$ $v 54.0 \mu \mathrm{g} / \mathrm{dl}$ ) or duration (11.4v $12.0 \mathrm{y})$. Of the urinary markers, only NAG showed a positive association with current blood $\mathrm{Pb} \quad(r=0.18$, $\mathrm{p}=0.01)$ and historical blood $\mathrm{Pb} \quad(r=0.21$, $\mathrm{p}=0.01$ ), but not with the other $\mathrm{Pb}$ exposure variables. These trends were not significant once the associations were modelled (table 4). The association of NAG with the percentage change in blood $\mathrm{Pb}$ concentration between the second last and last blood $\mathrm{Pb}$ measurement was also examined, in view of a recent finding along these lines. ${ }^{19}$ The median interval between the last two blood $\mathrm{Pb}$ values was 7.9 months and the median percentage change $3.5 \%$ (range -42 to 87). No association between NAG and recent change in blood $\mathrm{Pb}$ was found $(r=-0.06$, $\mathrm{p}=0.3)$. Epidermal growth factor was negatively associated with cumulative blood $\mathrm{Pb}(r=$ -0.18, $\mathrm{p}=0.04)$. No associations between $\mathrm{Pb}$ 
Table 5 Prevalence of abnormal renal markers and lead exposure in a South African battery making workforce

\begin{tabular}{|c|c|c|c|c|c|c|c|c|}
\hline & \multicolumn{2}{|c|}{$\begin{array}{l}\text { Serum creatinine } \\
\geqslant 125 \mu m o l / l \\
\text { Prevalence }\end{array}$} & \multirow[b]{2}{*}{ OR $(95 \% C I)$} & \multirow{2}{*}{$\begin{array}{l}\text { Serum uric } \\
\text { acid } \geqslant 500 \\
\mu m o l / l \\
\text { Prevalence } \\
(\%)\end{array}$} & \multirow[b]{2}{*}{ OR $(95 \% C I)$} & \multicolumn{2}{|c|}{$\begin{array}{l}\text { Urinary } N A G \geqslant 5 \\
\text { U/g creatinine } \\
\text { Prevalence }\end{array}$} & \multirow[b]{2}{*}{ OR $(95 \% C I)$} \\
\hline & $n$ & $(\%)$ & & & & $n$ & $(\%)$ & \\
\hline \multicolumn{9}{|c|}{ Current blood lead $(\mu \mathrm{g} / \mathrm{dl})$ : } \\
\hline $23-50$ & 160 & 2.5 & 1.0 & 1.9 & 1.0 & 88 & 20.5 & 1.0 \\
\hline $51-60$ & 115 & 7.8 & $3.3(0.99$ to 11.1$)$ & 5.2 & $2.8(0.6$ to 11.8$)$ & 59 & 22.0 & $1.0(0.4$ to 2.3$)$ \\
\hline $61-110$ & 101 & 9.9 & $4.4(1.3$ to 14.5$)$ & 11.9 & $7.9(2.1$ to 29.4$)$ & 48 & 29.2 & $1.6(0.7$ to 3.6$)$ \\
\hline \multicolumn{9}{|l|}{$\mathrm{ZPP}(\mu \mathrm{g} / \mathrm{g} \mathrm{Hb}):$} \\
\hline $1.9-10$ & 166 & 1.8 & 1.0 & 2.4 & 1.0 & 82 & 20.7 & 1.0 \\
\hline $10.1-20$ & 135 & 5.2 & $2.8(0.7$ to 11.3$)$ & 4.4 & $1.7(0.4$ to 6.3$)$ & 74 & 24.3 & $1.1(0.5$ to 2.5$)$ \\
\hline $20.1-104$ & 64 & 20.3 & $13.5(3.6$ to 50.4$)$ & 15.6 & $7.6(2.2$ to 26.5$)$ & 33 & 27.3 & $1.3(0.5$ to 3.5$)$ \\
\hline \multicolumn{9}{|l|}{ Duration $(\mathrm{y})$ : } \\
\hline $0.5-7.5$ & 124 & 4.9 & 1.0 & 2.4 & 1.0 & 64 & 21.9 & 1.0 \\
\hline $7.6-12.5$ & 112 & 3.6 & $0.6(0.1$ to 2.3$)$ & 3.6 & $1.3(0.2$ to 6.1$)$ & 57 & 28.1 & $1.4(0.6$ to 3.2$)$ \\
\hline $12.6-44.5$ & 146 & 8.9 & $1.3(0.4$ to 4.1$)$ & 9.6 & $3.2(0.8$ to 12.8$)$ & 77 & 19.5 & $0.7(0.3$ to 1.8$)$ \\
\hline \multicolumn{9}{|c|}{ Cumulative blood lead ( $\mu \mathrm{g} . \mathrm{y} / \mathrm{dl})$ : } \\
\hline $7-520.0$ & 123 & 4.1 & 1.0 & 4.1 & 1.0 & 63 & 19.1 & 1.0 \\
\hline $520.1-2681$ & 123 & 8.9 & $2.0(0.6$ to 6.3$)$ & 6.0 & $1.4(0.4$ to 4.5$)$ & 62 & 27.4 & $1.7(0.7$ to 4.1$)$ \\
\hline \multicolumn{9}{|c|}{ Historical blood lead $(\mu \mathrm{g} / \mathrm{dl})$ : } \\
\hline $14-60$ & 134 & 3.0 & 1.0 & 1.5 & 1.0 & 70 & 15.7 & 1.0 \\
\hline $61-96.3$ & 112 & 10.7 & $3.7(1.1$ to 12.0$)$ & 9.8 & $7.1(1.5$ to 33.8$)$ & 55 & 32.7 & $2.7(1.1$ to 6.6$)$ \\
\hline
\end{tabular}

${ }^{\star} \mathrm{OR}$ derived from a multiple logistic regression model, adjusted for age, height, and weight.

$\mathrm{NAG}=\mathrm{N}$-acetyl- $\beta$-D-glucosaminidase; $\mathrm{ZPP}=$ zinc protoporphyrin; $\mathrm{Hb}=$ haemoglobin.

exposure and any of the other urinary markers were found.

The findings in table 4 were re-examined by categorising the renal outcomes in terms of the proportion that fell above a normal upper limit (table 5). The number of exposure categories had to be reduced to accomodate the relatively few abnormal observations. The findings with this analysis were consistent with the trends found in table 4 .

In an analysis of haematological outcomes, ZPP was negatively associated with both packed cell volume and haemoglobin. Alcohol use and smoking were positively associated with packed cell volume, and alcohol use and weight with haemoglobin concentration.

\section{EFFECT MODIFICATION}

There was no interaction between alcohol and $\mathrm{Pb}$ in the effect on renal function or any of the urinary markers. Similarly, although smoking was associated with blood $\mathrm{Pb}(r=0.12, \mathrm{p}<0.05$, for current smoking and blood $\mathrm{Pb}$ ), there was no interaction between any of the smoking variables and $\mathrm{Pb}$ in the associations with renal outcomes.

Examination of an interaction between racial group and $\mathrm{Pb}$ exposure in the association with renal outcomes was limited by the few employees who were not black $(n=41)$. After excluding this group from the analysis, there was essentially no change in the associations found. The key analyses were repeated also after excluding the 20 monthly paid employees, with no change in the results.

\section{MEASUREMENTS AT TWO YEARS}

The mean (SD) tibial bone $\mathrm{Pb}$ in the random sample of 40 subjects measured at two years was 69.7 (35.5) $\mu \mathrm{g} / \mathrm{g}$ bone mineral, and median (range) $60.9 \mu \mathrm{g} / \mathrm{g}(22.6$ to 179.4$)$. Of the 56 blood $\mathrm{Cd}$ concentrations measured, 38 fell below the laboratory's level of detection of 0.5 $\mu \mathrm{g} / \mathrm{l}$, a further 17 were between $<0.5 \mu \mathrm{g} / 1$ and $0.9 \mu \mathrm{g} / \mathrm{l}$, and one reached $1.2 \mu \mathrm{g} / \mathrm{l}$.

\section{Discussion}

The main finding in this study is that blood $\mathrm{Pb}$ concentration, current and historical, and ZPP are associated with measures of renal impairment or injury, but not with blood pressure, in a South African workforce.

The threshold, if any, above which $\mathrm{Pb}$ absorption produces renal impairment is controversial. It has been suggested that maintenance of blood $\mathrm{Pb}$ concentrations $<70 \mu \mathrm{g} / \mathrm{dl}$ is sufficient to protect against adverse renal effects in most male workers. ${ }^{12}$ Thresholds are difficult to define, however, as no single measure of $\mathrm{Pb}$ exposure reflects the true cumulative dose to the kidney in all exposure situations.

In this workforce, with a mean duration of exposure of 11.6 years, and in which half the workforce had blood $\mathrm{Pb}$ measurements (measured currently or historically) of $<60 \mu \mathrm{g} / \mathrm{dl}$, robust exposure-response relations were found between serum creatinine and the $\mathrm{Pb}$ exposure measures assumed to have a substantial short term component - that is current blood $\mathrm{Pb}$ and ZPP. These associations were monotonic down to $<40 \mu \mathrm{g} / \mathrm{dl}$ and $5 \mu \mathrm{g} / \mathrm{g} \mathrm{Hb}$ respectively. Serum urea seemed to be influenced by ZPP, but not by blood $\mathrm{Pb}$.

The incompleteness of historical blood $\mathrm{Pb}$ information on the longer service workers was dealt with by restricting the analysis to workers on whom information on long term or cumulative measures of $\mathrm{Pb}$ exposure was available. Assuming that blood $\mathrm{Pb}$ concentrations were higher in the years before routine blood $\mathrm{Pb}$ testing than in recent years, the resulting censored group are likely to have had cumulative blood $\mathrm{Pb}$ and historical blood $\mathrm{Pb}$ concentrations that were lower than those of the workforce as a whole. However, this restriction would have reduced the power of the study to detect an effect. Systematic and random error could also have been introduced by varying indications for routine testing and by variability in the quality of laboratory measurement over time. 
Nevertheless, a similar exposure-response relation was found between historical blood $\mathrm{Pb}$ and creatinine as for the measures which included short term exposure components. However, renal function seemed to be uninfluenced by duration of exposure, and this was reflected also in the lack of association with cumulative blood $\mathrm{Pb}$.

Serum creatinine is a function of muscle mass and diet, as well as the glomerular filtration rate. ${ }^{22}$ Serum creatinine adjusted for age and weight, as was done in this study, provides a reasonable reflection of creatinine clearance. ${ }^{23}$ The increase in mean creatinine (and therefore decline in mean clearance) with each increment in blood $\mathrm{Pb}$ of $10 \mu \mathrm{g} / \mathrm{dl}$ (or in $\mathrm{ZPP}$ of $5 \mu \mathrm{g} / \mathrm{g}$ ) was small in this workforce. It is thought, however, that by the time serum creatinine rises above the clinical reference range, up to $60 \%$ of nephrons may be dysfunctional. ${ }^{24}$ The cumulative effect on the kidney of aging, $\mathrm{Pb}$ exposure, and other renal insults may thus become clinically important in some people, justifying measures aimed at preventing subclinical effects in exposed workers.

Uric acid too was found to show exposureresponse relations with current and historical blood $\mathrm{Pb}$ and $\mathrm{ZPP}$, which if causal may reflect an influence of $\mathrm{Pb}$ on the renal handling of urate. This handling is complex and may include glomerular filtration, reabsorption, tubular secretion, and postsecretory reabsorption. ${ }^{25}$ The mechanism of hyperuricaemia in $\mathrm{Pb}$ nephropathy is postulated to be due to increased tubular reabsorption of uric acid. ${ }^{26}$ Hyperuricaemia associated with increased $\mathrm{Pb}$ absorption could thus be interpreted at least in part as a measure of tubular dysfunction.

By contrast with the renal findings, there was no association between $\mathrm{Pb}$ and blood pressure in this workforce. Although a substantial proportion of the workforce had grown up in rural areas, the age standardised hypertension prevalence of $6.0 \%$ with the World Health Organisation definition (blood pressure $\geqslant 165$ / 90) was only slightly lower than the $6.8 \%$ found in a comparable but more urbanised population in Cape Town, ${ }^{27}$ suggesting little protective effect of a rural background. These hypertension prevalences are in turn low compared with those found in comparable population studies elsewhere in South Africa. ${ }^{3}$

We considered non-occupational sources of $\mathrm{Pb}$ among these subjects. Domestic sources of $\mathrm{Pb}$ in folk remedies and home brewed beer, or in batteries burned for fuel or in backyard smelting of $\mathrm{Pb}$, are possible sources, but there was no evidence to confirm any of these. Other possible environmental or occupational nephrotoxic exposures include $\mathrm{Cd}^{20}$ and arsine. ${ }^{28}$ Arsenic contamination of $\mathrm{Pb}$ was very low in the materials used in this factory. Cadmium is discussed later. Also, although alcohol intake was high in the workforce, and alcohol was independently associated with blood $\mathrm{Pb}$, uric acid, and blood pressure, no interaction of alcohol with $\mathrm{Pb}$ in the effect on renal function was found.
Another aim of the study was to determine if the use of urinary biomarkers was of any value in detecting and localising disturbance of the proximal tubules and other regions of the nephron by $\mathrm{Pb}$. The NAG activity includes that of two isoenzymes, reflective of different modes of disruption of cellular processes in the proximal tubules. ${ }^{19}{ }^{20}$ Retinol binding protein is a low molecular weight protein derived from serum reflecting tubular, particularly proximal tubular, damage. ${ }^{15}$ Other tubular markers are the isoforms of alkaline phosphatase, tissue non-specific alkaline phosphatase, and intestinal alkaline phosphatase, localised in the brush border of the proximal tubular cells. Tissue non-specific alkaline phosphatase is present mainly in the proximal convoluted tubule (S1-S2 segments), whereas intestinal alkaline phosphatase is found exclusively in the straight part of the proximal tubule ( 3 segment). ${ }^{14}$

Of these proximal tubular markers, NAG activity in the urine was above the reference range in almost a quarter of the samples tested and showed some correlation with current and historical blood $\mathrm{Pb}$, although not with recent changes in blood $\mathrm{Pb}$ as has been suggested. ${ }^{19}$ Although an increased urinary NAG activity has been found to be associated with some measure of $\mathrm{Pb}$ exposure in several studies $^{811-131929}$ only a few have shown an exposure-response correlation of NAG with blood $\mathrm{Pb} .{ }^{813}$ The interpretation of the change in NAG in workers exposed to $\mathrm{Pb}$ is thus contentious, and it has been argued that the apparent association is due to a confounding effect on the kidney of Cd intake. ${ }^{11}{ }^{12}{ }^{19}{ }^{21}$ In this study there was no $\mathrm{Cd}$ in the production process, and the median blood Cd concentration, a measure of recent absorption tested two years after the main study, was similar to concentrations in the non-smoking general population of $0.4-1.0 \mu \mathrm{g} / \mathrm{l}^{30}$ It seems implausible that $\mathrm{Cd}$ at such low concentrations could entirely explain the association, although limited, found between blood $\mathrm{Pb}$ and NAG in this population. However, as Cd concentrations were not measured at the same time as $\mathrm{Pb}$ in the main study, confounding could not be examined directly.

Tamm-Horsfall glycoprotein is found in the thick ascending limb of the loop of Henle and the early distal tubule, ${ }^{31}$ whereas the polypeptide epidermal growth factor seems to be associated with the thick ascending limb and distal tubule as well as the collecting ducts. ${ }^{32}$ Reduced expression of Tamm-Horsfall glycoprotein and epidermal growth factor is thought to reflect renal medullary dysfunction or early damage in these regions. Epidermal growth factor alone was negatively correlated with cumulative blood $\mathrm{Pb}$, but not with any of the shorter term $\mathrm{Pb}$ exposure measures. Finally, microalbuminuria (albuminuria varying between 30 and $300 \mathrm{mg} / 24$ hours) was measured as a reflection of glomerular damage; no association with $\mathrm{Pb}$ exposure was found.

Of the $\mathrm{Pb}$ exposure measures, blood $\mathrm{Pb}$ concentration (current or historical) and ZPP were consistent predictors of adverse renal effects in this study, with no absolute threshold for the appearance of such effects. The findings 
regarding creatinine are similar in some respects to those of Lilis et $a l^{6}$ among secondary $\mathrm{Pb}$ smelter workers $(21 \%$ with blood $\mathrm{Pb}$ concentration $>60 \mu \mathrm{g} / \mathrm{dl}$, but heavy previous exposure) and Pinto de Almeida et $a l^{33}$ among primary smelter workers in Brazil (mean blood $\mathrm{Pb} 62$ $\mu \mathrm{g} / \mathrm{dl})$. In both of these studies, positive associations between creatinine and ZPP were shown, whereas the association of creatinine with blood $\mathrm{Pb}$ concentration was less consistent.

By contrast, in studies of various groups exposed to $\mathrm{Pb}$ in Europe and Singapore with varying durations of exposure, in which the mean blood $\mathrm{Pb}$ concentrations were lower than in this study (between 30 and $51 \mu \mathrm{g} / \mathrm{dl}$ ), no association between serum creatinine and $\mathrm{Pb}$ exposure was found..$^{8-10121319}$

The findings in this study are consistent with a subclinical renal response to $\mathrm{Pb}$ that may start at blood $\mathrm{Pb}$ concentrations of between 40 and $50 \mu \mathrm{g} / \mathrm{dl}$. This was found for serum creatinine and urate, measures of relatively late disturbance of nephron function, as well as NAG, an early marker of proximal tubule disturbance. The most plausible explanation for the discrepancy between this study and the negative studies cited is the presence of a higher cumulative body burden of $\mathrm{Pb}$ in this workforce. It is probable that average past exposure in this workforce was heavy, as control regulation for occupational $\mathrm{Pb}$ was introduced into South African industry only in $1991,{ }^{34}$ setting the medical standard at $80 \mu \mathrm{g} / \mathrm{dl}$ blood $\mathrm{Pb}$.

Body burden in the form of bone $\mathrm{Pb}$ relative to renal function has recently begun to be measured in cross sectional workforce studies. In one study, no association between tibial $\mathrm{Pb}$ and renal function was found, ${ }^{10}$ whereas in the other tibial $\mathrm{Pb}$ was positively associated with a slight hyperfiltration state. ${ }^{12}$ Tibial bone $\mathrm{Pb}$ measurements done on a random fraction of the workforce in this study two years after the main study showed a median bone $\mathrm{Pb}$ concentration of $60.9 \mu \mathrm{g} / \mathrm{g}$. This is higher than has been reported in most occupational groups. ${ }^{10} 1835$ Surprisingly, it is similar to the tibial $\mathrm{Pb}$ concentrations reported among Belgian $\mathrm{Pb}$ smelter workers (geometric mean 65.8 $\mu \mathrm{g} / \mathrm{g}$, range 19.6 to 167.7$).{ }^{12}$ However, blood $\mathrm{Pb}$ and $\mathrm{ZPP}$ concentrations in the Belgian workers were much lower than in this study, suggesting that both current $\mathrm{Pb}$ exposure and the bone $\mathrm{Pb}$ store may contribute to the toxicologically active pool of $\mathrm{Pb}$. In a currently exposed workforce with heavy past exposure, blood $\mathrm{Pb}$ may thus remain a reasonable measure of renal $\mathrm{Pb}$ burden, whereas in less heavily exposed populations, either historically or currently, or in people no longer exposed, blood $\mathrm{Pb}$ is a poor measure of renal $\mathrm{Pb}$ burden. ${ }^{36}{ }^{37}$ Similarly, ZPP can be regarded as a measure integrating both recent and more remote $\mathrm{Pb}$ exposure and reflecting the biologically active renal $\mathrm{Pb}$ burden. ${ }^{38}$

The search for a coherent theory of $\mathrm{Pb}$ nephrotoxicity is somewhat complicated by recent population studies which have shown an association between creatinine ${ }^{39} 40$ and creatinine clearance ${ }^{39}$ and blood $\mathrm{Pb}$ at very low con- centrations, of the order of $10 \mu \mathrm{g} / \mathrm{dl}$, as well as with ZPP of the order of $1.0 \mu \mathrm{g} / \mathrm{g} \mathrm{Hb}$. It is speculated that if real, these associations may be indicative of a biphasic response of the kidney to $\mathrm{Pb}$, one at higher concentrations found in occupational groups and one at the very low concentrations typical of the general population..$^{40}$

Finally, this study confirms the need to amend the South African medical blood $\mathrm{Pb}$ standard of $80 \mu \mathrm{g} / \mathrm{dl}$ downwards towards internationally accepted levels. ${ }^{34}$

The study ensued from an agreement between the Chemical Workers' Industrial Union and the employing company. The study was made possible by grants from the Medical Research study was made possible by grants from the Medical Research
Council of South Africa, the De Beers Chairman's Educational Trust, the Medical Faculty of the University of Cape Town, the University of Michigan Office of the Vice President for University of Michigan Office of the Vice President for
Research, and the United States Public Health Service. The Research, and the United States Public Health Service. The
South African Institute for Medical Research waived payment for laboratory testing. Professor Jonny Myers and Dr Richard Wedeen, contributed to the design of the study, while Sr Denise O'Hagan, Oracular Sinqingqi, Brian Wilson, Isaac Ceshembe, and Sr M Maqina played important parts in its execution. Geert Behets carried out the analyses of the urinary markers. Dr Brian Rayner provided nephrological advice. Helpful comments on the results and manuscript were received from Professors Jonny Myers, Mark Cullen, Stefan Maritz, and Leslie London.

\section{Appendix 1: Laboratory methods}

Serum biochemistry was measured on a Technicon RAXT autoanalyser by the following methods: creatinine, Jaffe rate method; urea, urease method linked to the oxidation of NADH; uric acid, uricase method with production of hydrogen peroxide reacting quantitatively to form a quinoimine dye. Haemoglobin was measured colorimetrically on a Technicon $\mathrm{H} 1$ autoanalyser.

$\mathrm{N}$-acetyl- $\beta$-D-glucosaminidase was measured with a colorometric kit (Boehringer Mannheim, Germany). Retinol binding protein was measured by an automated continuous flow non-isotopic immunoassay based on latex particle agglutination. Tissue non-specific alkaline phosphatase and intestinal alkaline phosphatase were measured with two commercially available enzyme linked immunosorbent assay (ELISA) kits (Innogenetics, Belgium), TammHorsfall glycoprotein, and microalbuminuria by ELISA (Elias, Germany), and epidermal growth factor by competitive ELISA. Urinary creatinine was measured by a modified Jaffe reaction. (Further details available from authors on request).

\section{Appendix 2: SI conversion factors}

\begin{tabular}{ll}
\hline Blood lead & $1 \mu \mathrm{mol} / 1=20.7 \mu \mathrm{g} / \mathrm{dl}$ \\
Zinc protoporphyrin & $1 \mu \mathrm{mol} / 1=62.6 \mu \mathrm{g} / \mathrm{dl}$ \\
Creatinine & $88.4 \mu \mathrm{mol} / 1=1 \mathrm{mg} / \mathrm{dl}$ \\
Urea & $0.166 \mathrm{mmol} / 1=1 \mathrm{mg} / \mathrm{dl}$ \\
Uric acid & $60 \mu \mathrm{mol} / 1=1 \mathrm{mg} / \mathrm{dl}$ \\
\hline
\end{tabular}

1 Cullen MR, Robins JM, Eskenazi B. Adult inorganic lead intoxication; presentation of 31 new cases and a review of recent advances in the literature. Medicine 1983;62:221-47.

2 Landrigan PJ. Lead in the modern workplace. Am f Public Health 1990;80:907-8

3 Seedat YK, Seedat MA, Hackland DBT. Prevalence of hypertension in the urban and rural Zulu. F Epidemiol Community Health 1982;36:256-61.

4 Mollentze WF, Moore AJ, Steyn AF, et al. Coronary heart disease risk factors in a rural and urban Orange Free State black population. $S$ Afr Med $\mathcal{f} 1995 ; 85: 90-6$.

5 Lilis R, Gavrilescu N, Nestorescu B, et al. Nephropathy in chronic lead poisoning. Br f Ind Med 1968;25:196-202.

6 Lilis R, Fischbein A, Valciukas JA, et al. Kidney function and lead: relationships in several occupational groups with different levels of exposure. Am F Ind Med 1980;1:405-12. 
7 Buchet JP, Roels H, Bernard A, et al. Assessment of renal function of workers exposed to lead, cadmium, or mercury ccup Med 1980;22:741-50.

8 Verschoor M, Wibowo A, Herber R, et al. Influence of occupational low-level lead exposure on renal parameters. $A m \mathcal{F}$ Ind Med 1987;12:341-5.

9 Gennart J-P, Bernard A, Lauwerys R. Assessment of thyroid, testes, kidney and autonomic nervous system function in lead-exposed workers. Int Arch Occup Environ Health 1992;64:49-57.

10 Gerhardsson L, Chettle DR, Englyst V, et al. Kidney effects in long term exposed smelter workers. Br f Ind Med 1992; 49:186-92.

11 Cardenas A, Roels H, Bernard AM, et al. Markers of early renal changes induced by industrial pollutants. II Application to workers exposed to lead. Br f Ind Med 1993:50:2836.

12 Roels H, Lauwerys R, Konings J, et al. Renal function and hyperfiltration in lead smelter workers with high bone lead. Occup Environ Med 1994;51:505-12.

13 Dos Santos AC, Colacciopo S, Dal Bo' CMR, et al. Occupational exposure to lead, kidney function tests, and blood pressure. Am F Ind Med 1994;26:635-43.

man intestinal versus tissue non-specific alkaline phosphatase as complimentary urinary markers for the proximal tubule. Kidney Int 1994;46 S43-51.

15 Lauwerys RR, Bernard A. Early detection of the nephrotoxic effects of industrial chemicals: state of the art and future prospects. Am F Ind Med 1987;11:275-85.

16 Staessen JA, Bulpitt CJ, Fagard R, et al. Hypertension caused by low level lead exposure: myth or fact? $f$ Cardiovasc Risk 1994;1:87-97.

17 Hertz-Picciotto I, Croft J. Review of the relation betwen blood lead and blood pressure. Epidemiol Rev 1993;15:35273.

18 Somervaille LJ, Chettle DR, Scott MC, et al. In vivo tibia lead measurements as an index of cumulative exposure in occupationally exposed subjects. Br f Ind Med 1988;45: 174-81.

19 Chia KS, Mutti A, Tan C, et al. Urinary N-acetyl- $\beta$-Dglucosaminidase activity in workers exposed to inorganic lead. Occup Environ Med 1994;51:125-29.

20 Bernard A, Thielemans $\mathrm{N}$, Roels $\mathrm{H}$, et al. Association between NAG-B and cadmium with no evidence of a threshold. Occup Environ Med 1995;52:177-80.

21 Roels H, Bernard A, Lauwerys R. Urinary N-acetyl- $\beta$-Dglucosaminidase and exposure to inorganic lead (reply) Occup Environ Med 1995;52:285-6.

22 Cameron JS. Renal function testing. In: Cameron S, Davison AM, Grunefeld J-P, et al, eds. Oxford textbook of clinical nephropathy 2nd ed. Oxford: Oxford University Press, 1992;1:24-49.

23 Cockroft DW, Gault MH. Prediction of creatinine clearance from serum creatinine. Nephron 1976;16:31-41.
24 Zilva JF, Pannall PR, Mayne PD. Clinical chemistry in diagnosis and treatment. 5th ed. London: Edward Arnold, diagnosis
$1988: 18$.

25 Verberckmoes R. Uric acid and the kidney. In: Cameron S, Davison AM, Grunefeld J-P, et al, eds. Oxford textbook of clinical nephropathy, 2nd ed. Oxford: Oxford University Press, 1992;2:825-37.

26 Emmerson BT, Mirosch W, Douglas JB. The relative contributions of tubular reabsorption and secretion to urate excretion in lead nephropathy. Aust NZ F Med 1971;4:35362 .

27 Steyn K, Jooste PL, Bourne L, et al. Risk factors for coronary heart disease in the black population of the Cape Peninsula. S Afr Med f 1991;79:480-5.

28 Landrigan PJ, Costello RJ, Stringer WT. Occupational exposure to arsine. Scand F Work Environ Health 1982;8: 169-77.

29 Meyer RB, Fischbein A, Rosenman K, et al. Increased urinary enzyme excretion in workers exposed to nephrotoxic chemicals. Am f Med 1984;76:989-98.

30 American Conference of Governmental Industrial Hygienists. Documentation of the threshold limit values and biological ists. Documentation of the threshold limit values and biolc
exposure indices. 5th ed. Cincinatti, 1988:BEI 55-8.

31 Thornley C, Dawnay A, Cattel WR. Human TammHorsfall glycoprotein: urinary and plasma levels in normal subjects and patients with renal disease determined by a fully validated radioimmunoassay. Clin Sci 1985;68:52935

32 Verstrepen WA, Nouwen EJ, De Broe ME. Renal epidermal growth factor and insulin-like growth factor I in acute renal failure. Nephrol Dial Transplant 1994;9(suppl 4):57-68.

33 Pinto de Almeida AR, Carvalho FM, Spinola AG, et al. Renal dysfunction in Brazilian lead workers. Am $\mathcal{F}$ Nephrol 1987;7:455-58

34 Ehrlich RI, Myers JE. Control of occupational exposure to lead. $S$ Afr Med F 1991;80:260-61.

35 Erkilla J, Riihimaki V, Aitio A, et al. In vivo measurements of lead in bone at four anatomical sites: long term lead in bone at four anatomical sites: long term
occupational and consequent endogenous exposure. $\mathrm{Br} \mathcal{F}$ occupational and consequen

36 Bleecker ML, McNeill FE, Lindgren KN, et al. Relationship between bone lead and other indices of lead exposure in smelter workers. Toxicol Lett 1995;77:241-8.

37 Wedeen RP, Mallik DK, Batuman V. Detection and treatment of occupational lead nephropathy. Arch Intern Med 1979;139:53-7.

38 Grandjean P, Jorgensen PJ, Viskum S. Temporal and interindividual variation in erythrocyte zinc-protoporphyrin in lead exposed workers. Br F Ind Med 1991;48:254-7.

39 Staessen JA, Lauwerys RR, Buchet J-P, et al. Impairment of renal function with increasing blood lead concentrations in the general population. $N$ Engl f Med 1992;327:151-6.

$40 \mathrm{Kim}$ R, Rotnitzky A, Sparrow D, et al. A longitudinal study of low-level lead exposure and impairment of renal function. $\mathcal{F} A M A$ 1996;275:1177-81.

\section{Correspondence and editorials}

Occupational and Environmental Medicine welcomes correspondence relating to any of the material appearing in the journal. Results from preliminary or small scale studies may also be published in the correspondence column if this seems appropriate. Letters should be not more than 500 words in length and contain a minimum of references. Tables and figures should be kept to an absolute minimum. Letters are accepted on the understanding that they be subject to editorial revision and shortening.

The journal also publishes editorials which are normally specially commissioned. The Editor welcomes suggestions regarding suitable topics; those wishing to submit an editorial, however, should do so only after discussion with the Editor. 